\title{
ARAGON -VALENCIA: Holy Grail Territory
}

\author{
Ana Mafé García ${ }^{1, *}$, M. Lynne La Mantia ${ }^{2}$, Sergio Solsona Palma ${ }^{3}$ \\ ${ }^{1}$ University of Valencia, Spain \\ ${ }^{2}$ Commission of Investigations on the Holy Grail of the Cultural Association of the Route of the Holy Grail, Spain \\ ${ }^{3}$ Proyecto ENCUVA, València, Spain
}

Copyright $\bigcirc 2017$ by authors, all rights reserved. Authors agree that this article remains permanently open access under the terms of the Creative Commons Attribution License 4.0 International License

\begin{abstract}
The objective of the present study is to show the importance of creating a touristic description of a region or a locality based on its history that will be of interest to a visitor. There is no doubt that the curious tourist who possesses the knowledge of the past will experience an enhanced appreciation for the destination visited. The methodology to achieve this objective begins with research into the literary traditions based on the pursuit of the Holy Grail. It was widespread throughout Medieval Europe and revived at the end of the XIX Century in France and Great Britain. In addition, we searched for the historic sources that inspired the legends that were based on the deeds which took place in the Kingdom of Aragon and its territories between the XI and XIV Centuries. As human beings, the search for inner divinity is a reality that we cannot overlook. Everywhere we go there is a legend, an initiatory journey that induces us to connect with this inner divinity of ours and with Nature itself. We propose an example found in Spanish lands that can be used to envisage and to extrapolate stories of inner growth. These stories can be used by the tourists who visit these locations to increase their enjoyment of the new experiences related to an understanding of humanity and its inherent goodness. They will travel roads that have always existed and now, more than ever, are being taken again. This paper ends recommendations that future research should focus on the combined efforts of the regions of Aragon and Valencia for a structuring the Route of the Holy Grail, in order to offer the tourist an experience based on historical facts.
\end{abstract}

Keywords Holy Grail, Holy Grail Route, Chrétien de Troyes, Aragon, Valencia, Santo Grial, Grail, King Arthur, Camino del Santo Grial, Santo Cáliz de València

\section{Introduction}

The present text corresponds to a section of the doctoral thesis research ${ }^{1}$ on the relic known as the Holy Chalice, venerated in the Cathedral of Valencia, Spain. We have agreed to present a part of our hypothesis in this article with the purpose of encouraging collaboration in the construction of a new design for the touristic structuring of a territory. We feel that this possibility has not been studied sufficiently in its relation to the Route of the Grail. ${ }^{2}$ This route was presented in FITUR 2017 and was well received and promoted among the relevant administrative authorities. ${ }^{3}$ Because it is a nascent product in the Spanish territory, its foundations have to be consolidated through persuasive arguments to all involved so that tourists and adventurous travelers have an optimum experience.

We believe, therefore, that the field of Art History should provide the tourismologist with the necessary tools to achieve a common goal: the construction of a touristic product that has merit and substance, ancestry and roots, is unique and exciting. In short, an exploration of a legendary past is resuscitated by the iconographic and historic study of a territory. For this, we consider it necessary to carry out multi-disciplinary academic research regarding all of the factors ${ }^{4}$ which can influence the creation of a touristic experience.

The search for the grail as seen in the study of medieval literature serves as an example in our thesis. Therefore, in our study we have used the plot of two of the most interesting

1 This scientific article is written based on the hypothesis that the grail in the romance de Chrétien de Troyes is the same object as the grail that was until 1399 in the Real Monasterio de San Juan de la Peña, in Huesca, very close to Jaca. This possibility is defended in the doctoral thesis that is being written by Ms Ana Mafe Garcia of the University of Valencia, School of Geography and History, Department of History of Art, scholarship awarded by CENTRO ÓPTICO LOSAN to research the Holy Chalice, distinguished relic currently safeguarded in the Cathedral of Valencia, ultimately responsible for all the medieval literature regarding the research and knowledge of it.

2 It must be commented that those who have been working on this route, in the non-public sector since 2000 are those members of the Asociación Cultural "El Camino del Santo Grial", organization that will be duly presented in the corpus of the doctorate.

3 Here we are referring to the Valencian Tourism Agency of the Comunitat Valenciana.

4 In the same way as the human being is a holistic entity in the process of thought and feeling, so should be the multidiscipline teams that encompass the construction of tourist experiences (Mafé, 2016). 
novels of Chrétien de Troyes (ca. 1150- ca. 1183) which marked a milestone in the world of medieval literature.

Our research methodology for this article focuses on a more historic perspective than a literary one, consisting primarily of detecting historic figures and studying their lives in the Kingdom of Aragon without delving into a literary analysis of the persons in the novel. Once they are identified, it is not our aim to establish the possible links between the history of the Crown of Aragon and the characters and plots that are reflected in the works of Chrétien de Troyes. In these works, we have discovered parallels that to date have not been disseminated.

We started with a careful reading of one of the many manuscripts of the work by Chrétien de Troyes, ${ }^{5}$ selecting the manuscript $T$ version of Professor William Roach found in the Paris National Library (fr. 12576), using as a reference Li contes del graal because according to Dr. Martin de Riquer (2003), Troyes is the first author to name and talk about the graal.

During our research process, we have observed that the original text in the romance language (ancien français) marks an inflexion point different from translations that, without meaning to, result in a masking of the author's voice.

We followed the same process with the next work that we analyzed: Li chevaliers de la charrete (o Lancelot). We compared the lines of the plot of this romance with part of the history that we already have of the court of Aragon embodied by Alfonso I el Batallador and Doña Urraca I of Leon and we show how this story could have reached the ears of Chrétien de Troyes almost a century later.

In this line of argument, we note the possibility that the city of Jaca was used as the model for the mythical city of Camelot through references to another city that Chrétien himself names when he refers to the itinerant court of King Arthur.

The article concludes with a final reflection: we have to keep in mind that the content corresponds to part of the thesis that is being more fully developed in the expectation that a touristic description can crystallize the experience of the Route the Grail between the territories of Aragon and Valencia.

\footnotetext{
${ }^{5}$ Chrétien de Troyes died before he could finish the work he called Li contes del graal. There are, among many other versions, four documented Continuations, written by Wauchier de Denain, Manessier y Gerbert de Montreuil, between the end of the XII Century and the years 1230. These authors tried to untangle the mysteries left unresolved by Chrétien - the bloodied lance, the broken sword, the Fisher King, the grail - transforming the knightly adventures in an initiatory journey for knowledge or the mystic search for the grail creating from their own imagination new elements that originally are not found in the text of Chrétien. These novels that come after the work of the master similarly depict the personages of Perceval and Gauvain, following the wake of Arthurian inspiration. This all indicates a generous effort to conclude the text as well as suggesting the impossibility of revealing its mystery. Hence, we have resorted to the same text that Dr. Martín de Riquer, medievalist and specialist in troubadour literature replicates in his work Chrétien de Troyes. Li contes del graal. Re-edited in 2003 by Acantilado.
}

\section{Chrétien De Troyes - A Brief Introduction to His Sources}

The sources of inspiration that Chrétien used in his tales about desires and ambitions, encounters and battles, love affairs and challenges can be studied in relation to four issues that can be extrapolated to any artist according to the synchronic and diachronic analysis that we present based on the iconological method: ${ }^{6}$

- The past that antecedes the author; that is, the works that Chrétien read or knew about which had in some form nurtured and inspired his own style of literary creation.

- The literary style that was popular in the period, a style that had to be adhered to in order to please the person to whom the work was dedicated. In this case, Li chevaliers de la charrete (o Lancelot) is dedicated to Marie of France, Countess of Champagne (1145-1198).

- The weltanschauung ${ }^{7}$ which nurtured Chrétien de Troyes who was an active member of a society that possessed a political system, a system of ethical beliefs, a religious system, a productive system, and other elements.

- The experiences he lived and the cultural baggage he acquired.

We believe that beginning our research from the myth could lead to error in so far as it was not possible to follow a work method that could discern which information was fantasy and which was actually historically, culturally, traditionally and geographically close to accurate and definitely close to everything that today can be contrasted what we have identified as the Land of the Grail.

In reference to the first point, we return to the principal literary sources that nurture Chrétien de Troyes as a writer. According to the biography consulted, the research work carried out by de Riquer (2003), Chrétien in his youth translated the works Remedia Amoris, Ars Amatoria and Metamorphoses, by Ovid (43 A.C. -17 D.C.) unconsciously adopting a very meticulous and profound poetic style with regards to human psyche.

In the XII Century, three principal types of literary themes could be found in the libraries of the courts of Christian nobles:

- The Holy Scriptures, Psalters and prayer books always related to the Catholic religion with works from the Old and New Testaments and perfectly illustrated.

- Translated classical works or copies of them given as gifts by nobles and the abbots of the monasteries where they were kept.

6 As a starting point we used the method of studying images proposed by Panofsky (1892-1968).

7 German term that loosely means worldview, the way a person looks at life in a given moment and at a given place. 
- $\quad$ Also romances (chivalric romances written in verse) in which the theme was usually chivalric love, an epic recreation of the past or anything to do with chivalry.

\subsection{Chanson de Roland (Song of Roland): Building on a Myth as a Style of Writing}

The oldest epic poem known in Europe is the Song of Roland (c. 1100), an Old French epic poem inspired by the Battle of Roncevaux between the Vascons and the Carolingian troops which were led by Count Roland (c. 778). This historic deed, mentioned in different chronicles, takes place three hundred years before the legendary transformation of the event.

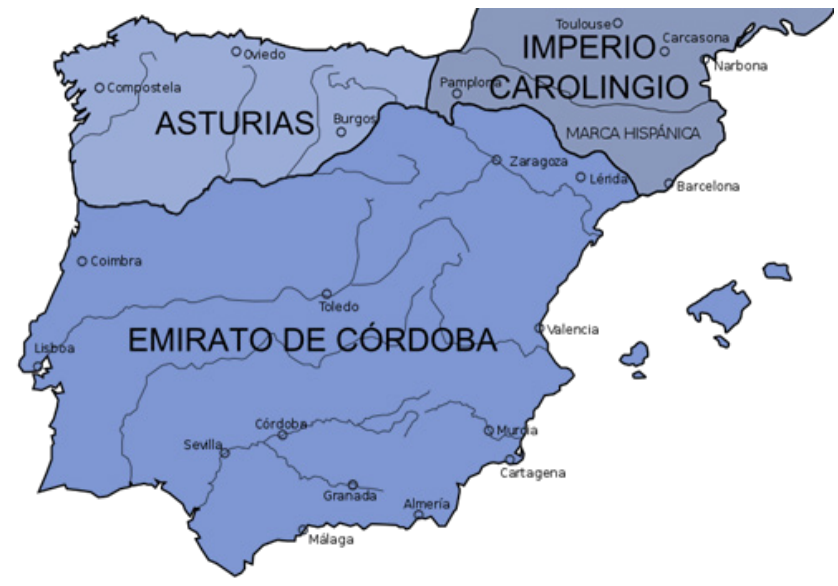

Figure 1. Situation of the borders of the Iberian Peninsula, c A.D. 800 Prepared by authors

Originally, Roland took part in an attempt by Charlemagne to expand his empire downward as far as Zaragoza by taking advantage of the fact that Sulaymán al-Arabi, Wali (governor) of Barcelona (c. 777-780) sought to rise up against the emir of Cordoba. In this uprising, the Wali hoped to have the support of the Franks in exchange for surrendering Saraqusta (present day Zaragoza).

When the Wali did not keep his word after receiving the help solicited, the French forces marched toward Pamplona and conquered it. Taking the Wali as a hostage, the French forces returned by the only passage through the Pyrenees that allowed them to shorten the route. However, it was exactly the same route that they had used previously, and the rear-guard troops led by Roland are ambushed in one of the mountain passes, the soldiers of Roland are defeated and Roland dies. The Saracen hostage is freed by his brother and allies. The chronicles of the period tell that his family governed Barcelona for a decade and a half more.

In the poem Song of Roland, these same deeds are magnified and given an epic dimension. Count Roland is portrayed as Charlemagne's nephew and extraordinarily heroic. Olivier, an imaginary personage, accompanies him in battle and the ambush becomes a pitiless attack by 400,000 Saracens.
This manner of writing by medieval authors indicates that the idea of recreating and magnifying the deeds of the past, either by adding to the qualities of the possible doer (be it the king, army commander or villain) of the deed or by exaggerating the number of combatants, the means used, and the visible signs leading to victory, was an accepted style.

We can say then that, in the beginnings of medieval literature, the common practice was to use a historical deed and recreate it imaginatively. This practice was totally acceptable; a situation that would be difficult to condone today as we tend to visualize the past based on accurate recording and scientific analysis. ${ }^{8}$

\subsection{King Arthur: The Creation of a Personage as Protagonist of a Mythical Past}

The Court of King Arthur of Britain is another literary influence used by Chretien de Troyes as an axis. However, he was not the first to use it; the Arthurian legend is a phenomenon that had been extensively repeated in the British Isles from ages past.

According to the studies consulted (Faral, 1929), the legend seems to have started with a historic text, De Excidio et Conquestu Britanniae, written by the British monk Gildas (c. A.D. 572) with the intention of compiling in an epic style the accounts of the battles fought by the Britons against the Saracen domination.

Precisely, in one of the battles that is described, Gildas names a certain Ambrosius Aurelianus as a British leader of Roman descent who defeats the Saxons in Badon Mont. ${ }^{9}$

\footnotetext{
Arthur is designated by Mark, not as a sovereign, but " Dux belli" only, - fighting against the Saxons, with the kings of Britain; and though there were many, "ipso nobiliores," he commanded with success, in twelve engagements. Malmsbury and Huntingdon make him no other than general of the British forces; nor is be otherwise distinguished by the earliest and most authentic writers, by whom he is recorded. It is, perhaps, owing to his subordinate rank, that Gildas, who has recorded the battle of Baden -Mount, (c. 26.) which was advantageous to the Britons, and honourable to Arthur, has not mentioned him by name.

William of Newburgh was the first who charged the legend of Arthur with inconsistency, and on the revival of letters, so ridiculous did it appear, that it became a question if such a person ever existed. The detail of Mark is simple, and exhibits no extravagant improbabilities. His life in Mr. Roberts's Cambrian Popular Antiquities, may be consulted to advantage.
}

Figure 2. (Nennius, Anchorite, Gunn, 1819, p. 178) The "Historia Brittonum". London: John and Arthur Arch.

Two centuries later another historian, Nennius, gives more details about this same battle in chapter 56 of his Historia Brittonum (c. A.D. 800) and changes the name of the protagonist from Ambrosius Aurelianus to Arthur, calling him the "dux belli" (field commander) of the Britons.

8 The academic discipline of History was consolidated in the XIX Century. 9 See (Faral, 1929, TI, 1-39) 


\section{Irish. It might be profitable to treat more at large of the life of this saint, but it is now time to conclude this epitome of his labours.86 \\ [Here endeth the life of the holy bishop, Saint Patrick.] \\ (After this, the MSS. give as $\S 56$, the legend of king Arthur, which in this edition occurs in 50 .)

$$
\text { Genealogy of the kings of Bernicia. } 87
$$

\$57. Woden begat Beldeg, who begat Beornec, who begat Gethbrond, who begat Aluson, who begat Ingwi, who begat Edibrith, who begat Esa, who begat Eoppa, who begat Ida. But Ida had twelve sons, Adda, Belric, Theodric, Ethelric, Theodhere, Osmer, and one queen, Bearnoch, Ealric.

Figure 3. Nennius. (c. 800) HISTORIA BRITONUM. Done by JA Giles, for Cambridge medieval editions in $2000 . \quad$ In: http://www.yorku.csona/inpar/nennius_giles.pdf (06/01/2017).

We should explain here that in a newer re-edition of this manuscript, we have found that the aforementioned chapter 56 has been transcribed to a different site in the text. ${ }^{10}$

Without entering into a lengthy discussion on the manner that texts from the past were translated or transcribed, we wish to present another detail about the uncertain origin of the personage known as Arthur.

In this case, it concerns a material object, a witness from the past that continues to announce its message, this time as a tombstone inscription. The funerary memorial is in two pieces that are set into the wall of the Church of St Martin Podstrana, Croatia.

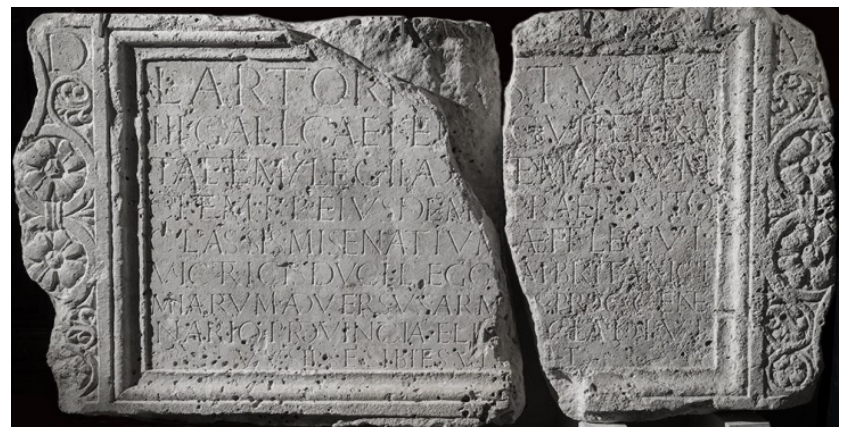

Figure 4. Image of the epitaph ${ }^{11}$ written on the two stone pieces. Public domain. Found in: http://christophergwinn.com/arthuriana/lac-sourcebook/ $(06 / 01 / 2016)$.

These two pieces of the epitaph tell us that L(ucio) Artorius Castus wrote this description of his career himself when he was serving as a Roman governor (procurator) in Liburnia, Dalmatia c. A.D. 200.

This short "autobiography" describes his various military positions and can be interpreted to show that he was sent to

10 The hypothesis of how narrated facts are transformed in each new historic edition or revision can be seen in this text.

11 Anthony Birley translates this as: "To the divine shades, Lucius Artorius Castus, centurion of the Third Legion Gallica, also centurion of the Sixth Legion Ferrata, also centurion of the Second Legion Adiutrix, also centurion of the Fifth Legion Macedonica, also chief centurion of the same legion, in charge of (Praepositus) the Misenum fleet, prefect* of the Sixth Legion Victrix, commander of two** British legions against the Armenians, centenary procurator of Liburnia with the power of the sword. He himself (set this up) for himself and his family in his lifetime.***" (Birley, 2005, $355)$.
Great Britain presumably to defend Adrian's Wall around the year A.D. 180.

The reason why we introduce this detail here is because of the wave of popularity of the hypothesis that this specific Roman soldier Lucius Artorius Castus was the "real" King Arthur. This thesis supported by such authors as Linda Malcor and C. Scott Littleton, who have written various articles and books about this subject. The plot of the 2004 film King Arthur ${ }^{12}$ is based on the hypothesis of Malcor and Littleton about Lucius Artorius Castus with Dr. Malcor working on the film as a consultant.

Christopher Gwinn, a specialist in Proto-Indo-European and old Celtic and medieval languages has collected all the information that he was able to find on the two Latin inscriptions in a research article. ${ }^{13}$ According to his findings, there were possibly three stone pieces instead of two. He carried out his analysis with the idea of gathering information on the inscription and everything known about this ancient Roman soldier.

As researchers, we wanted to provide an idea of the trail left by the inscription in stone so that the hypothesis about the mythical "Arthur" can be followed, keeping in mind the historicity of the Arthur personage.

Therefore, in this scenario of reinventing past deeds, the troubadours and medieval poets did not create their works from the rigorous methodology of collecting and contrasting information. This task was unthinkable for that time period. Instead, the romances were nourished by the re-creation of history through stories and legends.

Since the VI Century when a primeval genealogy of governors related to a territory first appears, volumes about the history of the British Isles, almost fanciful, have been successively elaborated. This work methodology is credible for the time period and additionally fulfils certain objectives.

An example can be found by following what was said about a certain Ambrosius Aurelianus (c. A.D. 570), called "great warrior" by the British monk Gildas and who became "Arthur", a valiant Christian commander, when Nennius ${ }^{14}$

12 Coproduction USA-United Kingdom-Ireland, directed by Antoine Fuqua.

13 Chistopher Gwinn. Lucius Artorius Castus: A Sourcebook. See: http://christophergwinn.com/arthuriana/lac-sourcebook/ (06/01/2016).

14In the text by Nennius, translated by JA Gilesy for Cambridge medieval editions in 2000, commented earlier, we find a sole direct reference: "Then it was, that the magnanimous Arthur, with all the kings and military force of Britain, fought against the Saxons. And though there were many more noble than himself, yet he was twelve times chosen their commander, and was as often conqueror. The first battle in which he was engaged, was at the mouth of the river Gleni. The second, third, fourth, and fifth, were on another river, by the Britons called Duglas, in the region Linuis. The sixth, on the river Bassas. The seventh in the wood Celidon, which the Britons call Cat Coit Celidon. The eighth was near Gurnion castle where Arthur bore the image of the Holy Virgin, mother of God, upon his shoulders, and through the power of our Lord Jesus Christ, and the holy Mary, put the Saxons to flight, and pursued them the whole day with great slaughter. The ninth was at the City of Legion, Exeter. which is called Cair Lion. The tenth was on the banks of the river Trat Treuroit. The eleventh was on the mountain Breguoin, which we call Cat Bregion. The twelfth was a most severe contest, when Arthur penetrated to the hill of Badon. In this engagement, nine hundred and forty fell by his hand alone, no one but the Lord affording him assistance. In all these engagements the Britons were successful. For no strength can avail against the will of the Almighty. The more the Saxons were vanquished, the 
compiled the Historia Brittonum (c. A.D. 800).

It is fundamental to include here the following data related to the Catholic religion that was written after the eighth battle as told by Nennius (c. A.D. 833):

The eighth was near Gurnion castle where Arthur bore the image of the Holy Virgin, mother of God, upon his shoulders, and through the power of our Lord Jesus Christ, and the holy Mary, put the Saxons to flight, and pursued them the whole day with great slaughter. [...] In this engagement, nine hundred and forty fell by his hand alone, no one but the Lord affording him assistance. In all these engagements the Britons were successful.

In the IX Century, the British Isles were totally Christianized under the jurisdiction of Rome. This process had begun with the Synod of Whitby (A.D. 664) which marked the end of the ecclesiastic organizational model of the Irish, based on the network of monasteries that had no visible hierarchical superior, in contrast to the consolidation of the Roman ecclesiastic model based on territorially organized bishoprics and a rigid hierarchy, similar to a military command system.

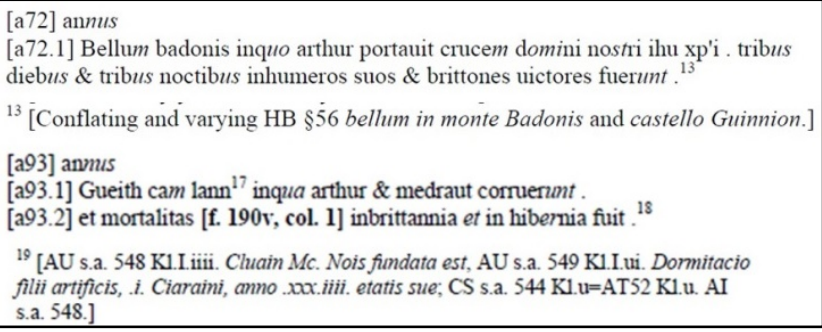

Figure 5. I Annales Cambriae The A text. Citations regarding Arthur on pp 3 and 4. Prepared by the authors. See the complete text in http://croniclau.bangor.ac.uk/documents/AC_A_first_edition.pdf (06/01/2017).

Thus, in this religious ambience, it is logical that Nennius himself, legendarily linked to the office of Bishop Elfodd De Gwynedd (c. A.D. 809), wrote this passage about Arthur, ascribing his victories to the image of the Holy Virgin, Mother of God to our Lord Jesus Christ and Father who aided him.

All of these additions of Christian symbolism crystallize the history of an Arthur who carries Christ's cross (c. A.D. 954) as seen in the work Annales Cambriae. more they sought for new supplies of Saxons from Germany; so that kings, commanders, and military bands were invited over form almost every province." In http://www.yorku.ca/inpar/nennius_giles.pdf (06/01/2017).

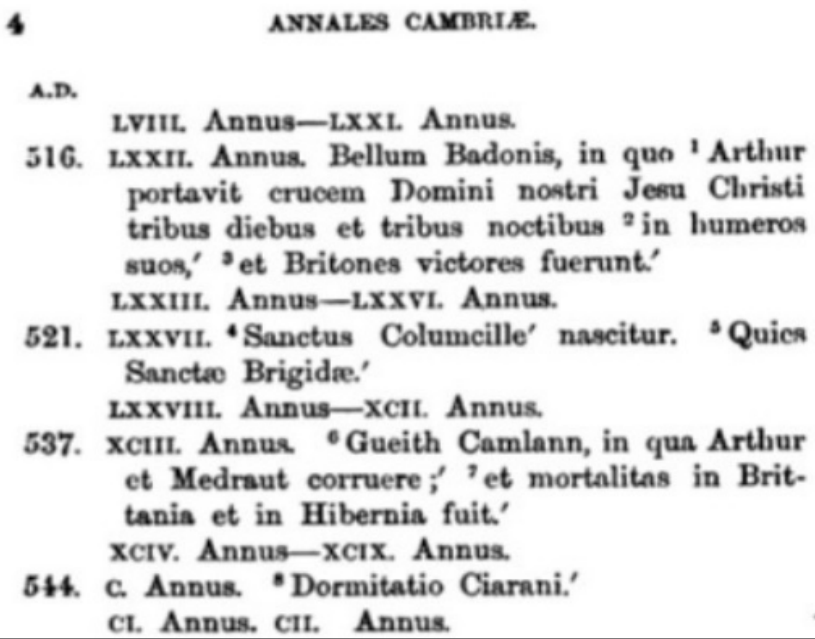

Figure 6. ANNALES CAMBRIÆ. Citations regarding Arthur between the years 516 and 537. P57. Prepared by the authors. See the complete text in https://ia801408.us.archive.org/2/items/annalescambriae00 willgoog/annale scambriae00willgoog.pdf (06-01-2017).

We have reviewed the verses where Arthur is specifically cited and we noted that in the Annales Cambriae chronicles compiled in the year A.D. 954, the title Rex does not yet appear before the name Arthur.

In the translation of the entries in Illustration 4, we again see a symbiosis between Arthur and Christianity:

(72). Year A.D. 516. The Battle of Badon, in which Arthur carried the Cross of our Lord Jesus Christ for three days and three nights upon his shoulders and the Britons were the victors.

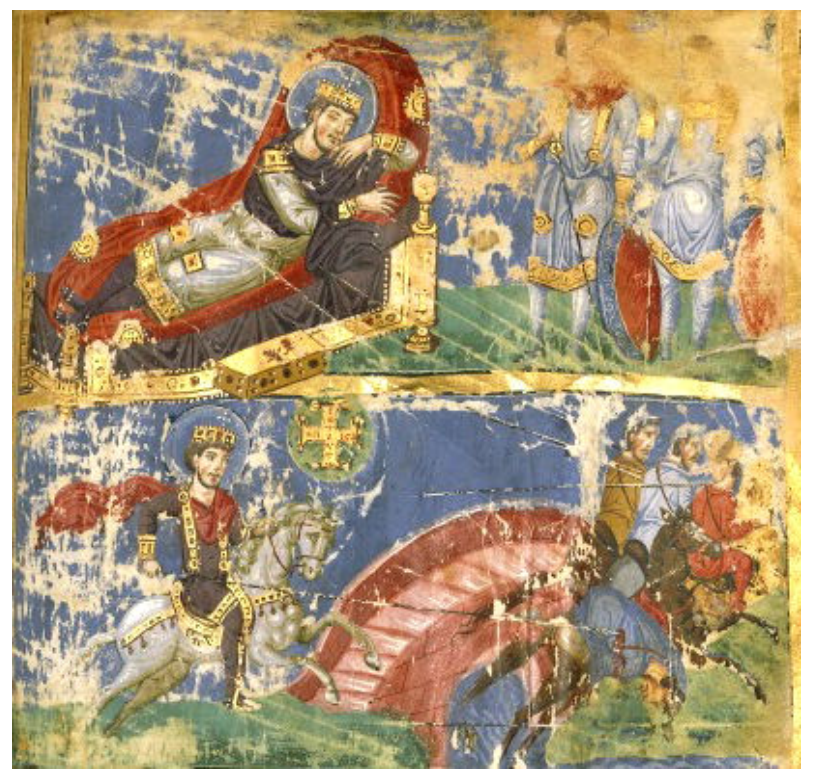

Figure 7. Dream of Constantine and the battle of Milvian. Homiles of Grégory de Nazianzus (BnF MS grec 510), folio 355. Dream of Constantine I and the battle of Milvian. (c. A.D. 879-882). Public domain. (C) French National Library. In https://commons. wikimedia.org/w/index.php?curid=1 $296395(08 / 01 / 2017)$ 
93) Year A.D. 537. The Battle of Camlann in which Arthur and Medraut (Mordred) are mortally wounded and there died in Britain and in Ireland.

In reference to this chapter in time, we can point out that six centuries had passed from the time when these historic annals were written until the establishment of Christianity as a religion in the old Roman Empire. Additionally, within this process of Christianization, there is a story about Emperor Constantine I that becomes a part of the imaginary deeds recounted by Christian chroniclers of the time period. The story tells us that before the Battle of the Milvian Bridge in A.D. 312 against his enemy Maxentius, Constantine saw in his dreams the sign of a cross in the sky, interpreting it to mean that he would win the battle with the help of Christ. Therefore, he adopted the new religion for all his empire.

Therefore, when the story is rewritten, the local warrior hero must be Christian and sanctified. Hence, the addition of details that were non-existent initially but, in keeping with the moment, were built upon a legendary past in order to construct a historic ancestry capable of rooting the legend in time as if it were a true event lived in that land.

In Vita Sancti Cadoci (c. 1067-1086), a hagiographic work about saints, Arthur is mentioned again. ${ }^{15}$

We leave this chronicle of British historic annals here because it is likely that Chrétien de Troyes knew of them and that they served as an inspiration when writing his romances.

Throughout this article we have verified that with the succession of chronicles, century after century, text after text, we can see an intention by the writers of the time to re-create a mythical personage when compiling the story without at any moment carrying out historiographic studies to document the facts. ${ }^{16}$

We can then ask ourselves why the writers reconstructed tales of the past without any type of paleographic or documental proof to verify the accuracy of them. We believe that the intention for this varies according to the century, i.e., the current historic moment.

Two issues arise when the first compilations of the royal genealogies of the continent (c. VI Century) are being collected and the boundaries between the territories are set: one, there is a need to legitimize royal power with an illustrious ancestry which can preserve the mandate of the lineage, and two, there is a need to look to the past for the name of a valiant warrior who resisted the onslaught of the domineering forces and freed the people from the yoke of bondage of the invading foreigner, in other words, a defender of the borders.

15 See: Torres Asensio, Gloria (2011), Los mitos de fundación: pervivencia en la hagiografía celtolatina medieval. Revista de Estudios Latinos (RELat) $11,67-80$.

16 The process of data gathering used in the beginnings of the Middle Ages, as commented previously, is not similar to historic research conducted in the XXI Century.
The emergence of royal genealogies as historic compendium in volumes and the idea of a local hero whose story can be re-elaborated and who takes on the role of the defender of the border, go beyond any physical condition. It is enough, then, to look to the past and choose the first warrior who marches against the enemy as commander of his army who at the end of his exploits always wins his battles and to confer on him this role in history, that of liberator.

Each new chronicle bestows a larger than life personality and fiction on the hero who, at that moment, represents a symbiotic being somewhere between the legendary monarch that he never was and the person carrying out the feats that nourish the romances and epic poems of the moment. This transfer of personalities enhances his legendary and epic past even more and culminates when it is incorporated into the a-historic context and then it seems as true evidence of the past.

\subsection{The mentors: Authors or Protagonists of the Romances Deferred}

As we have been illustrating, medieval literature used and re-elaborated the classic models. It contributed to the expansion of Latinity and Christianity by setting up a form for writing histories and stories. However, it was also nourished by the real lives and anecdotes that occurred in the different European courts.

A notable example is Phillip of Alsace (1143-1191), Count of Flanders to whom the $L i$ contes del graal is dedicated and who took up the cross in 1189 and departed on a crusade to Outremer in 1191 (de Riquer, 2003). The novel Li contes del graal by Chrétien de Troyes was written between the years 1178 and 1181 (Rita Lejeune, 1954). Therefore, the novel is conceived in a historic moment in which the two most important military conflicts of medieval Christianity are escalating: religious wars that intend to re-conquer Saracen territories in the Middle East (Holy Land) as well as in the West (Iberian Peninsula).

Flanders is geographically quite close to England, the place where the Arthurian legend started, according to what we have seen in the present article.

In his youth, Troyes wrote Erec (c. 1165), followed by Ciglés (c. 1176), Li chevaliersau Lion (or Ivain) (c. 1177) and Li chevaliers de la charrete (or Lancelot) (c. 1177), all of them about the Arthurian myth.

In the Chrétien de Troyes novel, Li contes del graal, the character of the knight who wants to belong to a court perfectly matches the profile of Troyes' mentor, the Count of Flanders, who has continuous feuds with the neighboring kingdom of France. (See illustration 8). 


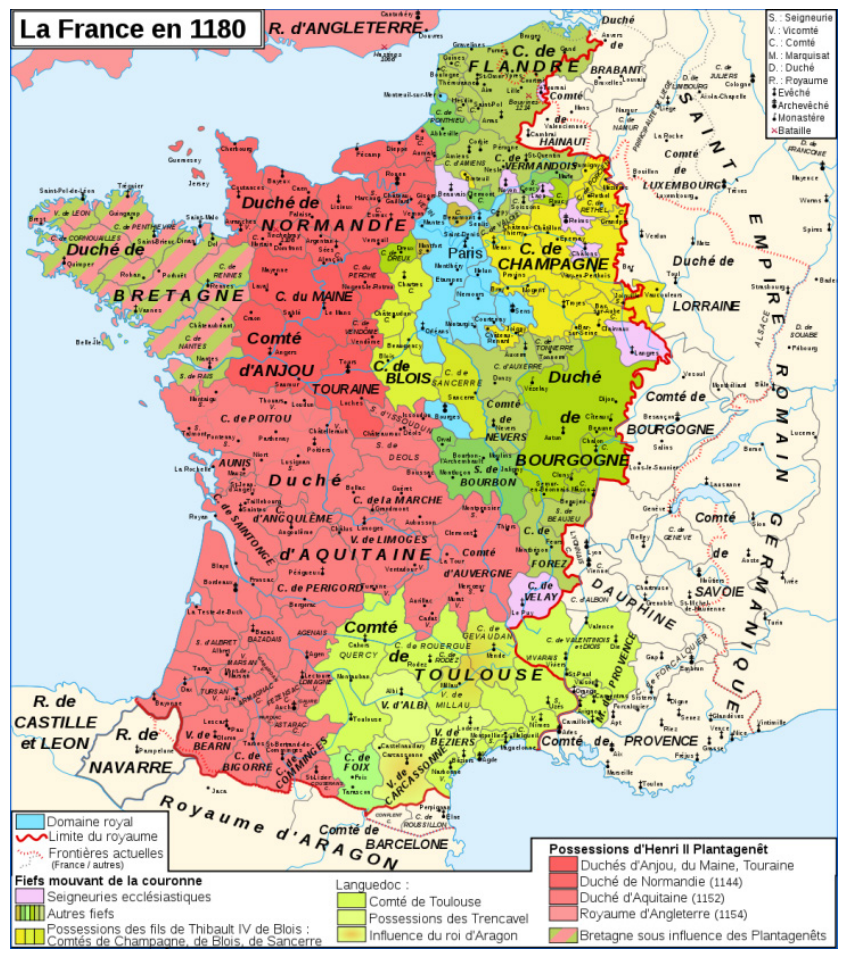

Figure 8. Zigeuner, from the work by William Shepherd, Historical Atlas, 1911. Public domain. In

http://www.cartesfrance.fr/histoire/cartes-royaume-capetiens/carte-royaum e-capetiens-1 180.html (08/01/2017).

The medieval writers knew that they had to gratify the person who was paying the cost of the work and so, when they wrote the romance, they did not consider including anything that did not create an emotional tie between the mentor and the protagonist of the principal plot.

That said, the topic of the romance cannot refer only to fueling the creative fires of other authors ${ }^{17}$ in the hopes that the flame of inspiration will revive a history around the same subject. We believe that Chrétien de Troyes must have adhered to the canons of ethical beliefs, to a religious system that was endorsed by an ecclesial power and the censor, while at the same time creating an imaginative parallelism with the court of Flanders (as in Li contes del graal). For that, he counted on fundamental elements such as those explained at the beginning of this article, namely his own experiences, his cultural baggage and his savoir faire.

On this point, we need to point out that Troyes was not only in Flanders but he also worked for Marie of France, Countess of Champagne (1145-1198) in the creation of a story full of passion and amorous encounters.

\section{Li Chevaliers de la Charrete (O Lancelot)}

The time proximity of the two works by the French troubadour - Li chevaliers de la charrete (o Lancelot) and $\mathrm{Li}$ contes del graal- leads us to suppose that the Crown of Aragon could be the generating image of these two narratives since, as previously explained, the process of how Arthur comes to life in the novels is through the response he has to the exploits and adventures of his knights. These ultimately seem to repeat well-known feats translated from the lives of persons in the most popular courts of the medieval European continent. In this case, the protagonists were the kings of Aragon and especially Alfonso I el Batallador (c. 1073-1134) who, through the movements of his armies, set up the Christian borders south of the Pyrenees and sent informative missives to the rest of the cross-Pyrenean courts.

Hence, King Arthur is not the only one who appears as a common subject in both medieval poems; other knights from that same court also appear in both romances. Among these we can find the noble Keu or "Galvan" as "Gauvain." This information points to the source of inspiration having the same thematic background.

We propose focusing on the personage of King Arthur and on his reign as a fount of inspiration for these two classic medieval works, in this case starting with the family relationship between Marie of France and the Crown of Aragon.

The Aragonese monarch Alfonso I married the heiress of the kingdom of León, Doña Urraca I in 1109. She was the daughter of the King of Castile and León, Alfonso VI (c. 1040-1109) and of Constance of Burgundy (1046-1093), granddaughter of King Robert II of France. From the analysis of this first marriage, it is clear, that there is a close relationship between the Kingdoms of France and of Aragon.

Chrétien de Troyes creates the romance of Lancelot for Marie of France, Countess of Champagne (1145-1198). Marie was the daughter of the marriage of Louis VII of France (1120-1180) and his first wife Eleanor of Aquitaine (1122-12040, an unhappy and unfortunate marriage that ended in annulment.

After the marriage was annulled and he had custody of his daughter Marie, Louis VII was married in 1154 to Constance of Castile (1136-1160), daughter of Alfonso VII of León called the "Emperador" and at the same time granddaughter of Doña Urraca I of León. Thus, Doña Urraca I of León was politically related to Marie of France through her stepmother.

17 The concept of plagiarism is a modern one. In the XI Century, it was normal for writers to copy one another, adding details depending on their own personal preference and their mentor. This is what occurred with the unfinished work Li contes del graal, which was later copied, lengthened and concluded. 
It seems plausible then that these tales about the court of León traveled with Princess Constance to Paris ${ }^{18}$ and there they nourished the infancy of Marie until her maturity when they later became the inspiration or motive for part of the work of Chrétien de Troyes. ${ }^{19}$

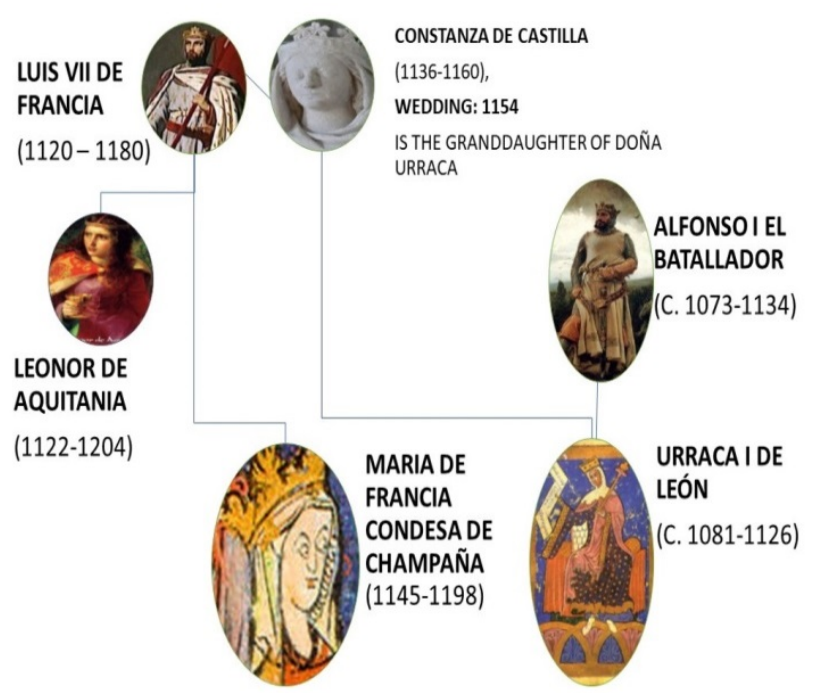

Figure 9. Diagram of relationships. Prepared by the authors.

\subsection{Doña Urraca of the Jimena Family and the Count of Lara: Guinevere and Lancelot}

Based on formal point of union between the historic genealogy that we have studied and the amorous history narrated in Li chevaliers de la charrete (o Lancelot), ${ }^{20}$ we can point to this couple as the possible protagonists who inspired the romance.

Doña Urraca I, Queen of León and descendent of the Jimena Family, was from an important royal lineage that was closely connected to the Northern Courts of the Pyrenees. Sancho Garcés III, the Mayor (c. 990 - 1035), King of Pamplona, was one of the founders of this family. He is considered the first Europeanist king because he was the first peninsular monarch who extended his relations further than the Pyrenees. It seems likely that the Guinevere who is portrayed as the queen in Troyes' work could have been inspired by this Aragonese genealogy.

The author himself as well as the transcribers writes her name in different forms. ${ }^{21}$ Queen Guinevere appears twice in this manuscript. ${ }^{22}$

18 Following the marriage of Eleanor of Aquitaine and Henry II of England, little Marie of France lived many years with Constance of Castile in the Parisian court of Louis VII, since he had been awarded custody of Marie by the King after the annulment of his previous marriage.

19 This parallelism was also pointed out by (Mandach, 1992) in Perceval. 20 Chevalier de la Charretteou Lancelot. Texte établi par P. Kunstmann. (Ottawa; Nancy, Université d'Ottawa, Laboratoire de Français Ancien; ATILF, 2009).

21 Phonetically the " $\mathrm{j}$ ” in Castilian Spanish, becomes " $g$ " in French because there is no transposition of such phoneme.

22 See note 5 .
- $\quad$ Con por la reïne Guenievre. (v.1099)

- Qu'ilquiert la reïne Ganievre. (v.3207)

If we phonetically transcribe the two names to Old French, we can see these similarities:

\section{Jimena vs. Ginebra \\ [3imena]vs. [3inebsa]}

The romance narrates some strange incidents that happen while Arthur is in Camelot: a knight comes to that court to inform them about some captive subjects. At the same time, the romance relates how Guinevere is abducted by Maleagant.

Since the king has other duties, it is Lancelot who rescues the queen from the castle where she is held prisoner and flees with her. They fall in love and surrender to amorous passion.

The flagrant adultery that both committed was the beginning of the end of the brotherhood of the round table in the literature of the Arthurian cycle. ${ }^{23}$ We must remember that at this time Guinevere is still the consort of King Arthur.

If we refer back to the history of the Aragonese court, after the marriage of Alfonso I of Aragon el Batallador to Doña Urraca I of León, the new queen went to the lands of Huesca, while later, around the year 1110, el Batallador attemped to subdue his new Leonese vassals who did not willingly accept the new king.

Precisely, it is in this time period of borders and pacts with the Saracens when some events develop, which completely coincide with one of the plots of Chrétien de Troyes in Lancelot.

Doña Urraca I of the Jimena family, the new regent of those lands of Huesca, had a dispute with her husband Alfonso I because she "rescued" some Muslim captives who were being held prisoner by him in the city of Jaca.

In the anonymous chronicles of Sahagún, ${ }^{24}$ we can read that between 1109 and 1111 the following happened:

"[... ] e aconsejada con los suyos, enbio arrahenes del rrei [del Rey Amidalon], e dados los arrehenes, rresgiuio del gran peso de oro e de plata, cogió, otrosí, e truxo para si algunos nobles de Aragón, los quales el rrei auia desterrado, e figolos pargioneros de su amistad»

The freeing of those prisoners caused the furious leader to go to the city of Jaca because his new wife Doña Urraca had kept the substantial ransom of the prisoners. Additionally, she had become friends with the exiled Aragonese nobles who in some way had helped her with the rescue.

23 The love between Guinevere and Lancelot is without a doubt one of the most repeated archetypes in romantic literature. It has inspired thousands of artists for centuries and has been reinterpreted in a multitude of versions. 24 (Puyol y Alonso, 1920, 55). 
The Crónica Compostelana ${ }^{25}$ retells some of what happened and it is told the way the chroniclers of the time period refer to it. ${ }^{26}$

9. De esta diferencia de Autores nació la diversidad que el mas diligente podrá notar en esta Obra, no solo en el estilo, sino en algunas materias, v. g. en el modo con que los primeros hablan de la hija de Don Alfonso VI, Doña Urraca, mas honorifico en los primeros que en el ultimo: porque quando aquellos escribieron no habia manifestado la Infanta la inconstancia y ligereza con que despues se portó.

Knowing how literary patterns make use of extrapolating real anecdotes into the world of fiction we can deduce that it is the same Alfonso I of Aragon who, transformed by his fury, incarnates the wicked Maleagant.

This anecdote, found in the historic annals, tells us that King Alfonso kept Queen Urraca captive in the castle of Castellar $^{27}$ and that she was able to escape thanks to the help of the nobles who were loyal to her.

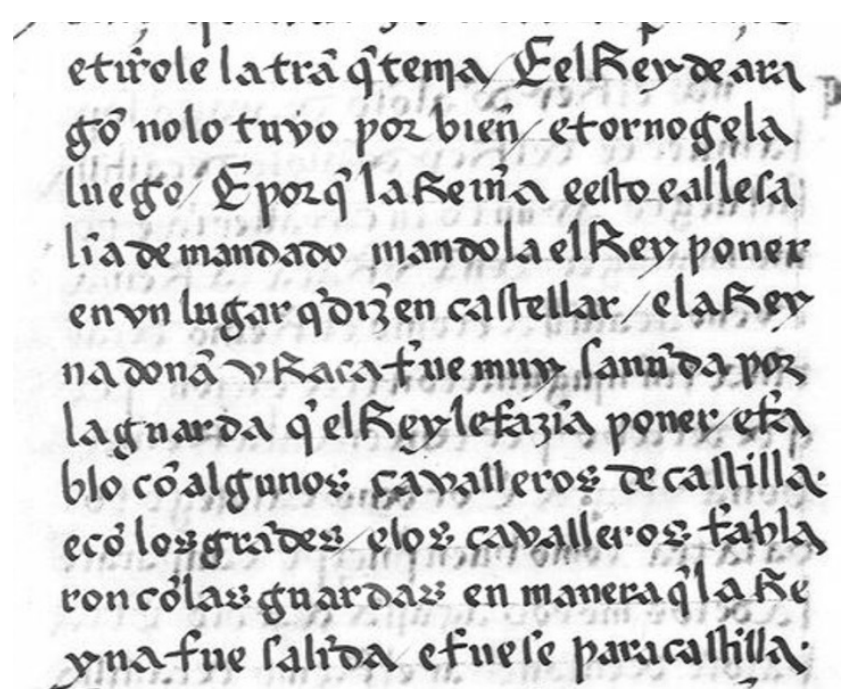

Figure 10. Jiménez de Rada, Rodrigo. (c.1430). Extract from p. 305 where the anger of King D. Alfonso with his wife doña Urraca is reflected. Prepared by the authors.

\section{[...] e por que la reyna en esto callera li a demandado}

25 We refer to the comment made by Henrique Flórez (1702-1773) in the work España sagrada. Theatro geographico-historico de la Iglesia de España.Tomo XX. Historia compostelana. $2^{a}$ edición. 179.

26 Doña Urraca is specifically mentioned more than 17 times in the alphabetic index of the Latin work. In later editions, among them, that of 1789, the index at the end of them is not the same. Proposed translation (by authors): "From this difference among authors came the diversity that the most diligent reader can notice in this work, not only in the style but also in some material; for example, in the way that the former talked of the daughter of Don Alfonso VI, Doña Urraca, more honorary in the first than in the last: because when the former wrote, the Infanta had not manifested the inconsistency and levity that her later behavior showed. "See: http://gallica.bnf.fr/ark:/12148/bpt6k92765t/f1.item.r =Espa $\% C 3 \% B 1 a \% 20$ sagrada.zoom (09/01/2017).

27 (Jiménez de Rada, c. 1430, 304-305). Proposed translation (by authors): [...] the king ordered her to be put in a place called Castellar. And Dona Urraca was very enraged by the guards that the king had ordered and she spoke with some knights of Castile and the knights spoke with the guards so that the queen was rescued and she went to Castile. mandadola el rey poner en un lugar que dicen castellar. e la reyna doña Urraca fue muy sañuda por la guarda que el rey le facia poner. efablo con algunos caualleros de castilla, e los caualleros fablaron con las guardas en manera que la reina fue salida e fuese para Castilla.

And since it could be no other way, among those who supported the queen was the count, Pedro González de Lara (v.1130) who, after the rescue, officially became her lover and with whom she had two children.

\section{Lara vs. Lancelot}

Interestingly enough, in the name Lancelot we can find a grammatical termination that coincides with the way diminutives are formed in Occitan language. ${ }^{28}$

Les diminutifs sont formés avec: et/eta, un ostalet, la cambreta, on/ona, un aucelon, una catona, òt/òta, un canhòt, la pauròt.

We believe that even without being married, Queen Dona Urraca, and De Lara had children together as contained in historical documents. Therefore, it can be affirmed that they were truly emotionally close because to lead a dissolute life in the court would be unthinkable at that time if it were not that Doña Urraca had extreme or truly influential power.

Nevertheless, the most interesting part of this history is the manner in which the count dies in real life - exactly as it is portrayed in the film adaptations of the death of Lancelot.

During the siege of the city of Bayonne, De Lara challenges Alfonso Jordán ${ }^{29}$ (1103-1148), Count of Tolosa and a direct family member of Doña Urraca, to a joust. In the combat with lances and shields, De Lara is wounded, falls from his horse and fractures his arm. It seems that some days later the wound worsened and October 16, 1130 is written as the date of death on an obituary in the Cathedral of Burgos.

\section{Laralot vs. Lancelot [Іаваlo] vs. [lãslo]}

This love story that ends in French lands could well have passed historic boundaries to become the storyline of

28 See on the page of the University of Montpellier: Mememto Grammatical Occitan. Languedocien. At: http://www.univ-montp3.fr/occitan/images/stories/memento_gramatical.pd $\mathrm{f}(09 / 01 / 2017)$.

29 According to what appears in the Chronica Adefons iImperatoris, Alfonso Jordán y Suero Vermúdez (c. 1080-1138) seized the towers of the city of León, which were held by the opposing nobles, among them Pedro González de Lara, and handed them over to Alfonso VII who had previously attended in March 1126 the coronation of his cousin Alfonso VII de León. It seems that the custom of being accompanied by court troubadours facilitated the presence at these activities of the troubadour from Gascuña, Marcabrú, whose poetic activity encompasses approximately from 1130 to 1150 . And perhaps he was the one who told this "clandestine" history of love in France. 
amorous poetry where chivalric love gives way to knightly jousts that put an end to adulterous loves.

We now return to the text of Chrétien de Troyes to look at the cities where the royal courts of Arthur were held: Camelot and Carlion.

\section{Camelot: A Hypothesis about its Location}

In the version of the Queste del saint Graal inmanuscrit $K$ (Bibliothèque Municipale de Lyon, Palais des Arts $n^{\circ} 77$ ), we find these initial verses. ${ }^{30}$

[A la veille de la Pentecoste

quant li compaignon

de la table reonde

furent venu

a Kamaalot et il orent

oï le servisse et

l'envoloit metre les

tables a heure de]

nonne lors en[tra] [a cheval en la] sale une moutbele

In some versions of the epic poem Li chevaliers de la charrete (o Lancelot), we also find verses that reference the city of that legendary medieval kingdom.

As we have already seen, a large part of the novels of XIX Century romanticism have also been situated in the same place by their authors.

A un jor d'une Ascension

$\mathrm{Fu}$ venuz de vers Carlion

Li rois Artus et tenu ot

Cort molt riche à Camalot,

Si riche come au jor estut. ${ }^{31}$

We must point out that this verse is not repeated in any of the manuscripts that have come down to us today.

In the version closest to the original by Chrétien de Troyes (manuscript $T$ ) of the Li contes del graal, we did not find "Camalot" or Kamaalot" mentioned in any of the 9234 verses so we had to examine other manuscripts rewritten after his death to be able to reference it. ${ }^{32}$

Likewise, in the different manuscripts we consulted, the description of this city is not very precise. Therefore, we

30 It has to be explained that the text was originally mutilated so the reproduction of Li conte del graal that we studied has been added in this case to manuscrit $Z$ (Paris, $B N F n$ acq. fr 1119, folio 138 recto, colonne a becoming the text that is conserved today in Lyon. Manuscrit Lyon BM P.A. 77 Edition by Christiane Marchello-Nizia with the collaboration of Alexei Lavrentiev In: http://txm.bfm-corpus.org (09/01/2017) (Marked in blue are the verses added in manuscript $Z$ ).

31 Proposed translation: Upon a certain Ascension Day /King Arthur had come from Caerleon, /and had held a very magnificent court at Camelot/ as was fitting on such a day. Variations of MS. from Vatican published by M. Keller (K) and MS. of the Bibliothèque Nation. à Paris, Supl. Franc.inf ${ }^{\circ}, n^{\circ}$. 210 (B). Roman van Lancelot (1846-1849)-anoniem Lanceloet. Naar het (eenig-bekende) handschrift der Koninklijke Bibliotheek.

32 There seems to be a copy of Lancelot where this appears, but we have not yet found it. thought it more practical to identify other places cited in the Chrétien de Troyes version and compare them with historic data that corroborate the importance of the geographic location with the deeds narrated in the chronicles, in this case those pertaining to the Crown of Aragon.

The historic events closest to the epic account became the essential inspiration for the writers of the period. They continued giving life to the fictitious persons who are tied to locations within the Arthurian world.

Supposedly, the court of King Arthur was held in Carlion, a city which has not been located as such by British scholars of the Arthurian world. In fact, they speak of Caerleonón-Usk in the north of Newport, Wales as a possibility, even saying that Carlión and Dinasdarón ${ }^{33}$ are the same place.

On the other hand, we find the city of Carrión de los Condes which is mentioned in eight occasions in the Historia Compostelana (c. 1107-1049). At that time, it was a very important city as it was there in Carrión that two ecclesiastical councils were held and additionally, it presumably was a meeting place for itinerant courts. From this point on, we are going to call this area which could have inspired part of the Arthurian myth, the Grail Territory.

In the plot of the romance, Camelot should be near Carlión. It must be remembered that on this point Chrétien de Troyes is the first writer to tell us of a fisher king and of a grail that was safeguarded in a castle. According to Aragonese history that fact situates us in a kingdom which has its capital in a fortified city, i.e., Jaca. The city is flanked by the river Aragon forming the territorial border, only two or three days by horseback from Carlión - Carrión de los Condes. ${ }^{34}$

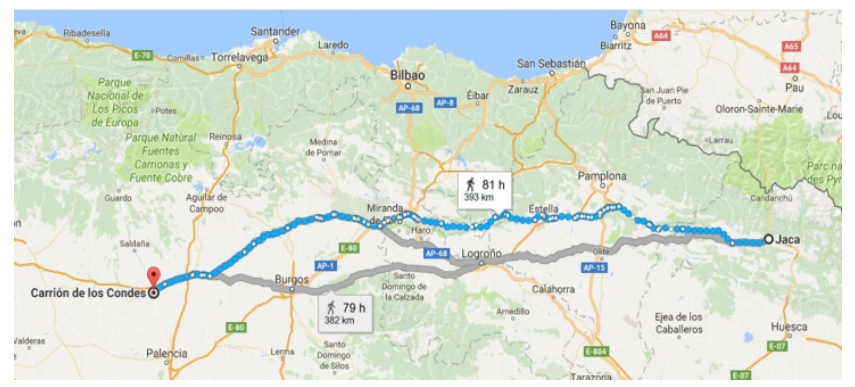

Figure 11. Geographic situation map that that shows from Carlión to Jaca. Google Maps. Prepared by authors.

It could be, then, that the fisher king and his court of knights is a reference to the kingdom of Alfonso I el Batallador, King of Aragon. Precisely, Aragon is the name of the river that crosses said kingdom and the similarity of King of a river vs Fisherman again seems reasonable

33 Another city where King Arthur's courts were held and which appears in the writings although we have not found a reference to said city in our research.

34 A horse at a walk covers approximately $6 \mathrm{~km} / \mathrm{hr}$; at a trot, between $16-$ $18 \mathrm{~km} / \mathrm{hr}$ and at a gallop, depending on size and rider, between 20 and 30 $\mathrm{km} / \mathrm{hr}$. If we figure an average of between $10-12 \mathrm{~km} / \mathrm{hr}$ and an 8-hour day at an easy rhythm, it takes barely three days to go from Carlión to Jaca. Just as it was insinuated in the romance. 
considering how Chrétien de Troyes masks the characters in his romances. It should not be forgotten that very close to the courtly city of Jaca, the Grail is safeguarded in the Royal Monastery of San Juan de La Peña, a fort-monastery embedded in the mountain, difficult to reach and impregnable.

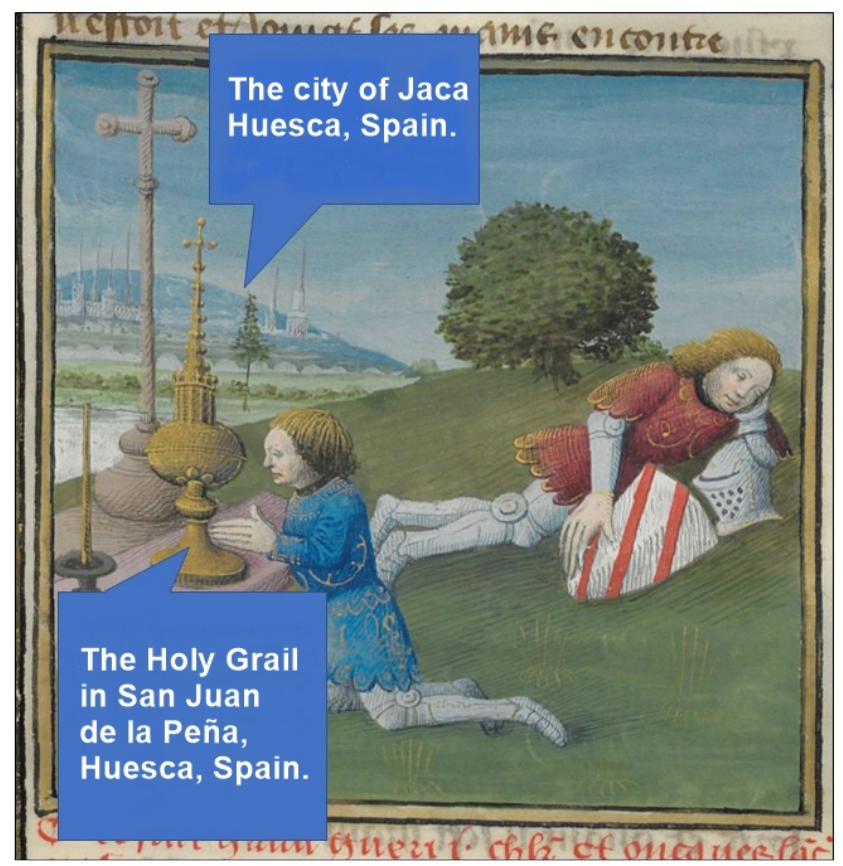

Figure 12. The Grail and in the background, Camelot. Text in illustration: Camelot as a walled city; the same as Jaca was in the Middle Ages. The Grail safeguarded at a very short distance from Jaca, at San Juan de la Peña. (translated by authors.) In the work Lancelot in prose. Français 116 1401-1500.Graal, 621r. Source: BnF, Bibliothèque nationale de France, Département des manuscrits, Français 116F. 577-735.

Again, we return to the parallelism between the phonetics and graphics of the Occitan language. In the Spanish language we have found this phonetic parallel, contrasting an ancient form of writing the name of Jaca and the written variant of Camelot:

\section{Chacalot vs. Chamelot [t $\mathrm{f}$ aka'lot] vs. [t $\left.\int \mathrm{ame}^{\prime} \mathrm{lot}\right]$}

In French, the phonetic transcription would continue to have many parallelisms in its pronunciation:

\section{Chacalot vs. Chamelot [jakalo] vs. [amlo]}

In the romances the city of Jaca would be referred to as "Jaquita", using a diminutive form and giving it a new meaning. It is possible that given the influences of the border with France, the city was the original inspiration of these provincial stories.

In concluding this section, we wish to mention that the German literary figure of Arthur, linked to the Grail in the XII and XIII Centuries, is transposed by the medieval Minnesänger, Wolfram von Eschenbach (ca. 1170 - ca. 1220) in his Parzifal (ca. 1200-1210). This work has been identified by diverse authors as a work that tells of an idealized Alfonso I, King of Aragon and Pamplona who reigned between 1104 and 1134.

Die Entdeckung des heiligen Grals, the research work by Michael Heseman, current member of the Cofradía del Santo Cáliz of Valencia must also be highlighted, as well as those by other researchers who have focused principally on a study of the classic work of Parzival by Wolfram von Eschenbach, dating it in the first quarter of the XIII Century. Mandach ${ }^{35}$ and Hasseman have suggested that the identity of other personages in these works corresponds to some of the nobles who served el Batallador.

This line in German research points the question of the whereabouts of the grail toward a clear direction: south of the Pyrenees. Not in vain does Richard Wagner (1810 -1883), in the opening of his opera Parsifal in 1882, write:

"Auf dem Gebiete und in der Burg der Gralshüter "Monsalvat"; Gegend im Charakter der nördlichen Gebirge des gotischen Spaniens».

The action takes place around and in the castle of Monsalvat; a land located in the northern mountains of Visigoth Spain. This information - the text about Lancelot and the coincidences found in the German opera Parsifal indicates without a doubt that Aragon is the Land of the Grail.

\section{Conclusions}

On a historiographic level and with the objective of creating a touristic explication, this article proposes a form of identification for both the place as well as for the deeds that may have planted the seed of the work of Chrétien de Troyes. This identification can be achieved through the defragmentation of the literary work according to the following suggested parameters.

First of all, the court of King Arthur is recognized as a genuine imaginary myth with varied storylines built upon by writers, historians, painters and, in the present time, the film industry. King Arthur is an ahistoric creation, probably known by all of the medieval writers because they themselves were the ones who, through their romances, gave him personality and soul by narrating the experiences and adventures of the real kings - in this case, of the Crown of Aragon - and then by adapting these feats into the stories.

Also, we are researching and learning about the mentors to

35 Mandach, Andree de. (1992). Le Roman du Graaloriginaire. Göppingen, Kümmerle. 
whom the work is dedicated. We think it is necessary to try to provide an insight into the influence that these medieval patrons might have had on the authors by studying, through known milestones, their genealogies, the education they received in the court and the desires that guided their lives. All of these aspects form a leitmotiv that surely would inspire and influence the author in his work, given that the situations and personages of the romance had to be recognized by whoever paid the author and, at the same time, by those who were complimented by his work.

In this scenario and in order for the phenomena of literary narrative to happen, there is an extrapolation of the history taking place in the royal courts toward chivalric literature, and instead of giving names and adjusting the specific geography in the romances, everything is masked, creating a parallel legendary universe with a symbiotic genesis, Arthurian continent with Aragonese contents. And, all of this is located in a limbo called Camelot.

Reading other works by authors that are contemporaries of Troyes indicates to us that this manner of glorifying the exploits of real persons through the poetry of troubadours is a constant in the medieval world.

Another critical point which has been less developed in the work of Chrétien de Troyes is the importance of the Way of St. James during the XII and XIII Centuries, known as the golden era of pilgrimages. According to the office of Reception of Pilgrims, ${ }^{36}$ the X and XI Centuries had a growing number of pilgrims but it is in the XII Century, owing to the energetic promotion by Archbishop Diego Gelmírez (1100-1140), that Santiago became a destination for Christian pilgrimages equaling Rome and Jerusalem.

Having studied the intermarriages between royal and noble lineages that continually took place; we see a series of chronologies about Santiago de Compostela that cannot be separated from the neighboring French lands. Therefore, these are listed in a separate appendix.

Continuing with the parallels found in the romances, we are certain that this evidence can be the beginning of new touristic exposition that collaborates in the creation of touristic experiences linked to a knowledge of the past and to the recovery of traditions and local culture. The inhabitants of each place in world geography have left a footprint, a pulse beat, an essence slow-cooked by history and by the passage of time.

For future research, we suggest that the texts used in creating a touristic description for a place or a land should be first editions or original manuscripts. Reliable reproductions should be consulted and not translations of them whenever possible because in the path between the primeval interests of the author and of the contemporary editors, many nuances and intentions which served as possible inspiration sources from original historic narratives can be lost. Thus, in this study we have used the oldest historic and literary

36 Oficina de Acogida del Peregrino. See in https://oficinadelperegrino.com/peregrinacion/introduccion/ (09/01/2017). manuscripts possible.

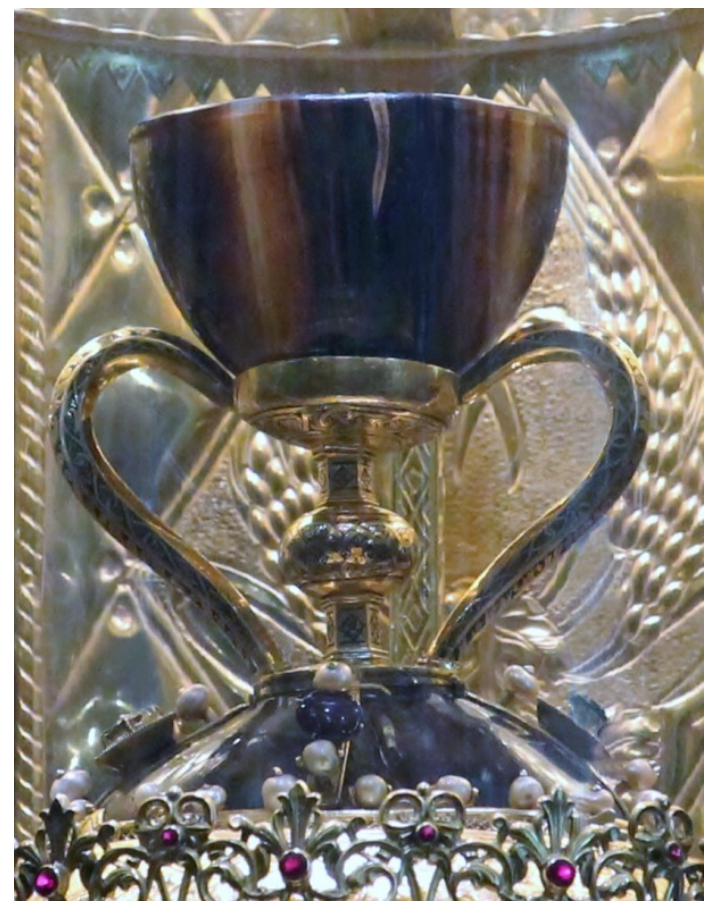

Figure 13. The Holy Grail refers to the upper cup that forms the Holy Chalice of the Cathedral of Valencia. Dated approximately in the 1st century $\mathrm{BC}$. The rest of the object is after the 10th century. Photograph by Ana Mafé García. February 2017.

We wish to affirm once again that what we have presented in this article corresponds to part of the thesis that more fully develops the link between the Land of the Grail and the communities of Valencia and Aragon. It has been necessary because of a lack of space to limit the subject of study to the two romances, $L i$ chevaliers de la charrete (o Lancelot) y $L i$ contes del graal, acknowledging that there is additional fundamental data to present regarding the Grail, its meaning and location.

Our objective in the current article can be summarized as a desire to recover the tales, stories and the legends of the past in order to transmit them in the form of a touristic description. This will help to structure a common territory with willing partners to form a network directed by tourismologists, who will be able to dynamize and highlight the touristic resources of the area, ultimately creating a common narrative to combine synergies, desires and dreams.

Once more, the necessity of showing the importance of a touristic exposition in promoting the value of tourist destinations and routes is evident because each place has a locus amoenus, an essence and history built on the actions of past generations with strong roots to tradition.

The knowledge, respect, study and dissemination of this shared history should arise from a reflection and criteria based on the study of the documental and artistic sources of each place. Additionally, oral tradition and local customs should reinforce this touristic exposition that, ultimately, supports a true artistic, cultural, historical and spiritual 
tourist experience.

Any comments and suggestions are welcomed so that we can constantly improve this template to satisfy all authors' research needs.

\section{Acknowledgements}

We are very grateful to the Losan Optical Center for their financial contributions to the study. To the Cultural Association the Route of the Holy Grail and to the Project ENCUVA, which allow us to develop this research activity around the Holy Chalice of the Cathedral of Valencia, worldwide known as the Holy Grail.

\section{REFERENCES}

[1] Annales. Annales Cambriae The A text. Transcribed by Henry W. Gough-Cooper. First edition (November 2015). Published online by the Welsh Chronicles Research Group: http://croniclau.bangor.ac.uk [6 January, 2009].

[2] Anonimo. Lancelot en prose. Codices illuminati mediiaevi 28. Farbmikrofiche - Edition der Handschrift. Bonn, Universitätsbibliothek, Handschrift S 526. Ulrich Mölk. (1992). München, Edition Helga Lengenfelder.

[3] Anonimo. (c. 1225-1230). Queste del saint Graal. Manuscrit Lyon BM P.A. 77. Edition by Christiane Marchello-Nizia Avec la collaboration de Alexei Lavrentiev. Lyon, BmL, 2013.

[4] Arco, R. (1919). El Real Monasterio de San Juan De La Peña. Jaca, Ed. de las Heras.

[5] Birley, A. (2005). The Roman Government of Britain. Oxford, OUP Oxford.

[6] Bonnat, A.R. (24 de diciembre de 1913). Desde París. A propósito de «Parsifal». La Correspondencia de España: diario universal de noticias, 1-2.

[7] Burdeus Pérez, $\mathrm{M}^{\mathrm{a}}$ D. (1998). Un viaje iniciático: Pierre Moinot o la reescritura de Chrétien de Troyes. In García-Sabell, Teresa (coord.) Les Chemins du texte: VI Coloquio da APFUE, Santiago, Universidad de Santiago, 97-108.

[8] Cajal, V. (8 de marzo de 1914). Parsifal y el turismo en el Alto Aragón. El Diario de Huesca.

[9] Doubleday, S. R. (2004). Los Lara. Nobleza y monarquía en la España Medieval. Madrid: Turner Publications, S.L. y C.S.I.

[10] Estepa Díez, C. (2014). El léxico de las relaciones personales en las Crónicas Anónimas de Sahagún. e-Spania en ligne : http://e-spania.revues.org/23851; DOI 10.4000/e-spania.2385 [6 January, 2009].

[11] Falque, E. (1984). El Manuscrito de la Historia Compostelana de la Biblioteca Capitular y Colombina. Habis, 17, 195-199.

[12] Faral, E. (1929). La légende arthurienne, études et documents lre partie: Les plus anciens textes. Paris, Champion. [3 vol. T.
I: Des origines à Geoffroy de Monmouth, 319 pages; T. II: Geoffroy de Monmouth, 463 pages; T. III: Documents, 389 pages et deux cartes].

[13] Hesemann, M. (2003). Die Entdeckung des heiligen Grals. Múnich, Pattloch.

[14] Jiménez de Rada, R. (c.1430). Crónica de España por el arzobispo de Toledo Don Rodrigo Jiménez de Rada, traducida al castellano y continuada por Don Gonzalo de la Hinojosa, Obispo de Burgos, y después por un anónimo hasta 1430 [Manuscrito]. Sevilla, Cartuja de Sevilla. P.304-305: http://bvpb.mcu.es/es/consulta/registro.cmd?id=451973 [6 January, 2009].

[15] Lejeune, R. (1954). La date du Conte du graal de Chrétien de Troyes. Le Moyen Age, LX, 51-79.

[16] Lejeune, R. (1957). La date du Conte du graal de Chrétien de Troyes. BBSIA, IX, 85-100.

[17] Lema Pueyo, J. A. (2008). Alfonso I el Batallador rey de Aragón y Pamplona (1104-1134). Gijón, Trea.

[18] Littleton, C. S., Malcor, L. (2000). From Scythia to Camelot: A Radical Reassessment of the Legends of King Arthur, the Knights of the Round Table and the Holy Grail. New York: Garland.

[19] Nazianze, G. de. (c.879-833). Homélies de saint Grégoire de Nazianze (BnF MS grec 510), folio 440. Songe de Constantin et bataille du pont Milvius.

[20] Nennius. (c.800). HISTORIA BRITONUM. Realizada por JA Giles, para ediciones medievales Cambridge en el año 2000: http://www.yorku.ca/inpar/nennius_giles.pdf [6 January, 2009].

[21] Nennius, Anchorite, M. the, Gunn,B. (1819). The "Historia Brittonum". London, John and Arthur Arch.

[22] Mafé García, A. (2016). The cultural tourism: an approximation to the term from the discipline of the history of the art. International Journal of Scientific Management and Tourism, 1(4), 193-199.

[23] Mafé García, A.; Pineda, R. A. C., \& Markovic, O. (2016). The scientific contributions of humanities to the study of cultural tourism from the departments of History of Art in Spain. International Journal of Scientific Management and Tourism, 2(1), 97-107.

[24] Mafé García, A.; Fons, M. V. S., \&Teruel, F. D. (2016). Valencia: Capilla del Santo Cáliz. Destino de peregrinos de la Ruta Europea del Santo Grial. International Journal of Scientific Management and Tourism, 2(2), 189-207.

[25] Gwinn, C. Lucius Artorius Castus: A Sourcebook: http://christophergwinn.com/arthuriana/lac-sourcebook/ [6 January, 2009].

[26] Mafé-García, A.(2016).Commissioning religious heritage value, through tourism: route of the Holy Grail in Valencia. International Journal of Development Research, Vol. 06, Issue, 08, 9244-9248.

[27] Mafé-García, A.; Alario-Bataller, S. (2016). The search for the grail as search for divinity reviewing cultural paradigms of the 21st century.International Journal of Current Research, 8 , (11), 41426-41430. 
[28] Malcor, L. (1999a). Lucius Artorius Castus, Part 1: An Officer and an Equestrian, Heroic Age, 1 (Spring/Summer): $\mathrm{http} / / / \mathrm{www} . h$ eroicage.org/issues/1/halac.htm $\quad[6$ January, 2009].

[29] Malcor, L. (1999b.). Lucius Artorius Castus, Part 2: The Battles in Britain. Heroic Age, 2 (Fall/Winter): http://www.heroicage.org/issues/2/ha2lac.htm [6 January, 2009].

[30] Mandach, A. de. (1992). Le Roman du Graal originaire. Göppingen, Kümmerle.

[31] Montaner Frutos, A. (2013). Introduction. e-Spania en ligne: http://e-spania.revues.org/22167; DOI:10.4000/e-spania.22167 [6 January, 2009].

[32] Orcasegui Gros, C. (1985). Crónica de San Juan de la Peña. (Versión Aragonesa). Edición crítica. CHJZ- 51-52, 419-569.

[33] Puyol y Alonso, J. (1920). Las crónicas anónimas de Sahagún: nueva edición conforme un ms. del siglo XVI estudio crítico por Julio Puyol y Alonso. Madrid, Establecimiento Tipográfico de Fontanet.

[34] Río Martínez, B.d'o. (1983). El Grial y Aragón. Revista de Ciencias Sociales del Instituto de Estudios Altoaragoneses, 95, 185-192.

[35] Riquer, M. (2003). Chrétien de Troyes. Li contes del graal.
Barcelona, Acantilado.

[36] Scottish Record Office. (1886). Rerum Britannicarum Medii Aevi Scriptores: Or Chronicles and Memorials of Great Britain and Ireland during the Middle Ages. No. 01-, Volumen 9, Parte 2. London: Rev. John Williams ab Ithel, M.A.: https://ia801408.us.archive.org/2/items/annalescambriae00wi llgoog/annalescambriae00willgoog.pdf [6 January, 2009].

[37] Torres Asensio, G. (2011). Los mitos de fundación: pervivencia en la hagiografía celtolatina medieval. Revista de Estudios Latinos (RELat) 11, 67-80.

[38] Troyes,C. de. (c.1171). Chevalier de la Charrette ou Lancelot. Texte établi par P. Kunstmann. (Ottawa; Nancy, Universitéd'Ottawa, Laboratoire de Français Ancien; ATILF, 2009).

[39] Trujillo Ballesta, J. Parzifal y Parsival en la obra de Wagner. (2011). Isla de Arriarán, XXXVIII, 299-329 Riquer, Martín d. (2003). Chrétien de Troyes. Li contes del graal. Barcelona, Acantilado.

[40] Universidad. Mememto Grammatical Occitan. Langue docien. Universidad de Montpellier: http://www.univ-montp3.fr/occitan/images/stories/memento gramatical.pdf [6 January, 2009].

[41] Williams, J. (1860). RERUM BRITANNICARUM MEDII AEVI SCRPTORES. ANNALES CAMBRIE. London, Logman. 